\title{
Earnings Per Share Reporting: A Movement Toward International Harmonization
}

Scott I. Jerris, (sjerris@sfsu.edu), San Francisco State University

\begin{abstract}
Earnings per share (EPS) is one of the most widely quoted financial measures used in assessing firm performance. Due to the use of the price-earnings ratio in financial analysis, some countries have established a standard for the computation of EPS measures. This paper compares, contrasts and illustrates current EPS reporting practices for two countries with actual pronouncements: the United States, and the United Kingdom. These two countries were specifically chosen because they represent how current EPS reporting practices can differ on a number of dimensions. In addition, this paper discusses the exposure draft of the Financial Accounting Standards Board (FASB) as compared to that of the International Accounting Standards Committee (IASC), based on a joint project to harmonize the reporting of EPS measures. Final passage of the exposure drafts is expected in mid-1997.
\end{abstract}

Introduction

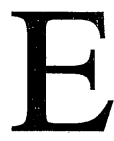
arnings per share (EPS) is one of the most frequently used financial measures to assess firm performance in a given year. Shareholders have used this measure as a means to assess the stewardship and management role performed by firm directors and managers. In addition, potential investors of equity capital have used earnings per share to compute the price-earnings ratio (PE) used in making buy or sell decisions. The reliance by potential investors on the PE ratio created an impetus for establishing a standard for earnings per share reporting across the world. For example, the United States' Accounting Principles Board issued Opinion No. 15, "Earnings Per Share," in 1969, the United Kingdom issued Statement of Stan-

Readers with comments or questions are encouraged to contact the authors via e-mail. dard Accounting Practice 3, "Earnings Per Share," in 1972, amended by FRS 3, "Reporting Financial Performance" in 1992.

While there was a similar notion of what earnings per share should be across these three nations, the way in which EPS was required to be computed differed in many significant ways (APB 15, 1969, SSAP 3, 1972). Hence for decades there was little international comparability with regard to the EPS ratio. In March 1994 the Financial Accounting Standards Board (FASB) added to its agenda an EPS project to be conducted concurrently with the International Accounting Standards Committee (IASC). This project pursued two goals: first, to simplify U.S. accounting rules on earnings per share, and second, to issue a standard that will be comparable to the one the IASC will issue (Accounting To- 
day, August 8, 1994, pp. 36). The FASB's proposal considered the IASC's idea of reporting basic and fully diluted earnings per share instead of primary and fully diluted earnings per share.

The FASB and IASC issued separate exposure drafts late in 1996 (FASB, 1996, IASC, 1996), and final passage by is expected in mid1997. If adopted, these standards are effective for fiscal years ending after December 15, 1997.

The remainder of this paper is organized as follows. The next two sections discuss, compares and contrasts current reporting practice for earnings per share in three countries: the United States, and the United Kingdom. These two countries were specifically chosen because they represent a sample of countries with quite different EPS reporting standards, thus showing a need for the joint FASB-IASC project. A comparison of EPS reporting in these two countries, before the joint project, is summarized in Table 1 . The last section of this paper discusses the FASB's exposure draft of a new EPS reporting standard, and how that standard improves international harmonization.

\section{EPS Reporting In The United States}

In 1969, the Accounting Principles Board issued Opinion No. 15, "Earnings Per Share." This pronouncement required firms with complex capital structures to present two types of earnings per share numbers: (1) primary earnings per share, based on the assumption that common stock equivalents are converted into common shares during the fiscal year, and (2) fully diluted earnings per share, based on the assumption that

Table 1

Comparison Of Eps Reporting Standards

\section{$\underline{\text { United States APB } 15 \quad \text { United Kingdom SSAP 3, FRS } 3}$}

EPS Measures

Mandatory

Equal Prominence

EPS reported for:

Antidilutives

Allowed?

Materiality

Threshold

Method of

conversion options

Method of

conversion conver-

tible debentures or

preferred primary, fully diluted

Yes

Yes

continuing operations, extraordinary items, discontinued operations, change in accounting principle, net income

No

$3 \%$

Treasury Stock Method for primary, fully diluted ${ }^{\mathrm{a}}$ If Converted Method for primary, fully diluted basic, fully diluted

Yes

Yes

continuing operations required
No

$5 \%$

Assume maximum conversion into common for fully diluted ${ }^{\mathrm{b}}$

If Converted Method for fully diluted

(a) the change in earnings (numerator) is assumed zero, except for the $20 \%$ rule.

(b) the proceeds from the options are assumed invested in $2.5 \%$ Consolidated Stock on the first day of the accounting period. 
all dilutive securities are converted into common shares during the fiscal year (APB 1969, I 15). The Accounting Principles Board predicted that the increased disclosure would provide users of financial statements with information as to the impact of potentially dilutive securities on earnings per share. To see an example of the application of APB Opinion No. 15, see Table 2, Panel A.

Primary and fully diluted earnings per share are permutations of basic or raw earnings per share, namely net income after dividends on preferred shares divided by a weighted-average number of common shares outstanding during the fiscal year. No dilutive securities are assumed to convert in the computation of basic earnings per share. Basic earnings per share is only reported on the income statement when it is not materially different from fully diluted earnings per share (the Board sets a three percent materiality threshold). If a material difference between basic and fully diluted earnings per share exists, then primary and fully diluted earnings are reported. Primary and fully diluted earnings per share need not be reported when the materiality threshold fails.

Firms with complex capital structures are those that have issued potentially dilutive securi-

Table 2

\section{Illustration Of Eps Reporting Standards}

The following information pertains to Global Company: Year Ended 12/31/96

From the income statement:

Income from continuing operations

Extraordinary items, net of tax

Net Income

$$
\begin{array}{r}
\$ 10,300,000 \\
4,000,000 \\
\$ 6,300,000
\end{array}
$$

From the balance sheet:

Long Term Debt

$10 \%$ convertible debentures

Shareholders' Equity

$\$ 1$ par Common Stock

\$1 par Preferred Stock

$$
\begin{array}{r}
\$ 10,000,000 \\
3,300,000 \\
600,000
\end{array}
$$

Additional Information:

- The $10 \%$ convertible debentures with a face amount of $\$ 10,000,000$, due October 1,2000 , were sold for cash at 98 on October 1,1990 . Each $\$ 1,000$ debenture is convertible into forty shares of common stock. At issuance the Aa corporate bond rate was $15 \%$. The discount is being amortized using the straight-line method.

- There are 3,300,000 common shares issued and outstanding at the end of 1996. There have been no conversions in 1996.

- The market price per common share was: $1 / 1 / 96 \$ 50,12 / 31 / 96 \$ 75$, and the average for 1996 was $\$ 80$.

- There are 600,000 shares of 20 cent cumulative preferred stock issued and outstanding at the end of 1996.

- Warrants to purchase 500,000 shares of common stock at $\$ 60$ per share for a period of five years were issued in 1993. None of these warrants have been exercised to date.

- The average tax rate is $40 \%$ 
Table 2

PANEL A: UNITED STATES (APB OPINION No. 15)

Basic EPS $=\frac{10,300,000-(600,000)(0.20)}{3,300,000}=\frac{10,180,000}{3,300,000}=3.08$

Common Stock Equivalents (CSEs):

Warrants : Yes, automatically.

Conv. Debt: The effective yield is $(10 \%)(1000 / 980)=10.20 \%$

$>(2 / 3)$ (Aa rate) $=(2 / 3)(15 \%)=10.00 \%$

Therefore, No.

For the warrants using the Treasury Stock Method - Primary:

$$
\frac{\Delta \mathrm{N}}{\Delta \mathrm{D}}=\frac{0}{(500,000-500,000(60 / 80))} \quad=\frac{0}{125,000}
$$

The Primary EPS calculation (only CSEs):

$$
\begin{aligned}
10,180,000 \div 3,300,000 & =3.08 \\
+\quad \frac{0}{10,180,000} \div \frac{125,000}{3,425,000} & =2.97 \text { Primary }
\end{aligned}
$$

For the warrants using the Treasury Stock Method - Fully Diluted:

$$
\frac{\Delta \mathrm{N}}{\Delta \mathrm{D}}=\frac{0}{(500,000-500,000(60 / 80))}=\frac{0}{125,000}
$$

since the higher of the average or ending prices is $\$ 80$.

For the conv. debt using the If-Converted Method:

$$
\frac{\Delta \mathrm{N}}{\Delta \mathrm{D}}=\frac{(1-.40)[(10 \%)(10,000,000)+(200,000) / 10]}{10,000(40)}=\frac{612,000}{400,000}
$$

The Fully Diluted EPS calculation:

$$
\begin{aligned}
10,180,000 \div 3,300,000 & =3.08 \\
+\frac{0}{10,180,000} \div \frac{125,000}{3,425,000} & =2.97 \\
+\frac{612,000}{10,792,000} \div \frac{400,000}{3,825,000} & =2.82 \text { Fully Diluted }
\end{aligned}
$$

The 3\% Materiality Test: $(97 \%)(3.08)=2.99>2.82$ So, Report Primary and Fully Diluted.

On the 1996 Income Statement show:

$\begin{array}{lll} & \text { Primary } & \text { Fully Diluted } \\ \text { Continuing Operations } & \$ 2.97 & \$ 2.82 \\ \text { Extraordinary Items } & \underline{(1.17)} & \underline{(1.05)} \\ \text { Net Income } & \underline{\$ 1.80} & \underline{\$ 1.77}\end{array}$

Extraordinary items EPS numbers are derived by dividing the $\$ 4,000,000$ by the number of shares in Primary and Fully Diluted, respectively. ties such as convertible debentures, convertible preferred stock, options, rights, or warrants that upon conversion or exercise could in the aggregate materially dilute earnings per share. Opinion No. 15 specifies how these potentially dilutive securities affect the computations of primary and fully diluted earnings per share. Firms with no dilutive securities (i.e., firms with a simple capital structure) need only report basic earnings per share.

Primary earnings per share can be considered as basic earnings per share adjusted for the dilutive effects of those securities classified as "common stock equivalents (CSEs)." Under Opinion No. 15 , a security whose value is "derived in large part from the value of the common stock to which it is related" (APB 1969, I 25 ) is treated as a common stock equivalent. Examples of this are stock rights, warrants, and options. For other dilutive securities such as convertible debentures and convertible preferred stock, common stock equivalency status is achieved if and only if at the time of issuance the security has an effective yield less than 66$2 / 3$ percent of the current average Aa corporate bond yield. A determination of common stock equivalency is made at the date of issuance and once that status is achieved (or not achieved), it remains regardless of the ensuing economic conditions of the issuing corporation. In the example found in Table 2, Panel A, the warrants are automatically considered CSEs, but the debt issue is not since the two-thirds Aa test was not met.

Common stock equivalents are included in the computation of primary earnings per share only if there is a dilution in the earnings per share ratio. Antidilutive securities (securities that increase the earnings per share ratio) are assumed never to convert. If dilutive, stock rights, warrants, and options are included in the primary earnings per share 
computation through the treasury stock method. Convertible debentures and convertible preferred stock, if classified as common stock equivalents and dilutive, are included in the primary earnings per share computation through the if-converted method.

The treasury stock method is used to determine the incremental number of shares upon exercise of stock rights, warrants, or options. The increment to the numerator under the treasury stock method is zero in most instances since there is no change in income or preferred dividends when stock rights, warrants, or options are exercised. In this method, the impact upon common shares is computed under the assumption that the dilutive securities were exercised at the beginning of the fiscal period and that the assumed proceeds obtained from the exercise were used by the firm to reacquire common shares at the average market price during the fiscal period. Hence in this method, the increment to the denominator of the earnings per share ratio is equal to the difference between the number of common sharers issued during exercise and the assumed number of common shares reacquired by the firm. This increment is positive when the average market price of the common shares is greater than the exercise or option price. In the example found in Table 2, Panel A, the impact on the denominator for primary and fully diluted EPS is 125,000 additional shares, while the change in the numerator is zero.

The if-converted method is used to assess the change in the earnings per share ratio for convertible debentures and convertible preferred shares. In this method conversion of these two dilutive securities, if not antidilutive, is assumed to occur at the beginning of the fiscal period. For convertible preferred shares, the increment to the denominator of the earnings per share ratio is equal to the number of preferred shares converted multiplied by the conversion ratio while the increment to the numerator is equal to the preferred dividend not paid after conversion. For convertible debentures, the increment to the denominator is equal to the number of debentures converted multiplied by the conversion ratio while the numerator is equal to the after-tax interest expense saved after conversion. In Table 2, Panel A, the if-converted method for the convertible debt issue results in a $\$ 612,000$ increment to the numerator and a 400,000 share increment to the denominator.

Fully diluted earnings per share can be considered as basic earnings per share adjusted for all dilutive securities, common stock equivalents as well as those not classified as such. Fully diluted represents the maximum possible dilution of common shares that can occur in a given fiscal period.

The computation of this earnings per share measure is quite similar to that of primary earnings per share. There are, however, two important differences. First, there are many more dilutive securities to examine since noncommon stock equivalents are included in the fully diluted computation. Second, the treasury stock method is modified so that the higher of the average or closing price per common share is used to determine the assumed number of treasury shares that a firm reacquires. This higher price leads to a greater number of shares assumed converted, and hence to a lower earnings per share.

If primary and fully diluted earnings per share meet the materiality test discussed above, then Opinion No. 15 clearly states that both these measures must be presented on the face of the income statement with equal prominence. In Table 2, Panel A, the $3 \%$ materiality test is met, thus primary EPS of $\$ 2.97$ and fully diluted EPS of $\$ 2.82$ must be shown on the income statement.

In addition, separate earnings per share numbers are also required for extraordinary items, cumulative effects of change in accounting principle, and income from discontinued operations if they occur during a fiscal period. As shown in Table 2, Panel A, separate earnings are indeed disclosed for the effect of extraordinary items. In practice two years of primary and fully diluted earnings per share numbers are required 
if comparative income statements are presented, which is often the case.

Opinion No. 15 attempted to provide the users of financial statements with useful information vis à vis the impact of potentially dilutive securities upon the earnings per share measure. However, this pronouncement was not without criticism in the United States. Much of this criticism centered on the choice of criteria determining common stock equivalence. Practitioners and academic researchers claimed that the ad hoc rules in Opinion No. 15 would produce numbers that would be too "noisy" and hence irrelevant in financial decision-making (Kross, Chapman, and Strand, 1980, Jerris, 1990-1, 1992a, 1992b). As will be discussed later in this paper, some new measure of dilutive earnings per share will required by generally accepted accounting principles in the United States when the FASB proposal becomes effective in 1997, twenty-five years after Opinion No. 15 was issued. This new measure will be called diluted EPS.

\section{EPS Reporting In The United Kingdom}

In February 1972, SSAP 3, "Earnings Per Share" was issued with the objective of providing a minimum standard for disclosure of EPS in financial statements and the basis of its calculation (Davies, Paterson and Wilson, 1989). As in the United States, the impetus for the standard was the increasing use of the price-earnings ratio in investors' buy/sell decisions. SSAP 3 was required for all companies who sell equity shares on the International Stock Exchange and the Unlisted Securities Market. Third Market companies were strongly encouraged, but not required, to comply with the accounting standard.

SSAP 3 was amended in 1992 by FRS 3, "Reporting Financial Performance." This amendment required that the numerator in the EPS metrics be based on income after extraordinary items. Prior to 1992, EPS measures were disclosed on the income statement for both before and after any extraordinary losses and gains. FRS 3 states, "To assess the performance of a reporting entity during a period all components of its activities must be considered" (Davies, Paterson, and Wilson, 1994). Hence the inclusion of extraordinary items in basic and fully diluted EPS is now mandatory. To see an example of the specific application of SSAP 3 as amended by FRS 3, see Table 2, Panel B.

U.K. GAAP requires two earnings per share numbers, basic earnings per share and fully diluted earnings per share, to be reported on the face of the profit and loss account (i.e., income statement) both for the current and for the previous fiscal period. In addition, the manner in which earnings per share was calculated must be disclosed in the statement itself or in the notes.

Basic earnings per share can be considered as income less preferred dividends and minority interests divided by the number of common sharers issued and eligible for dividend payment in the current fiscal period. In Table 2, Panel B, basic EPS is computed as $\$ 1.87$ per share, after extraordinary items.

When a firm has issued a separate class of equity shares which may be eligible for dividend payments in a future period, or when the firm's capital structure contains convertible securities, options or warrants, a calculation of an additional earnings per share measure labeled fully diluted earnings per share is required. This measure is required to be shown on the face of the profit and loss account with equal prominence. In addition, the basis of calculation of fully diluted earnings per share must be disclosed.

When a firm has options or warrants outstanding, fully diluted earnings per share should be calculated on the assumption that the maximum number of new shares had been exercised on the first day of the fiscal period if the dilutive securities were outstanding during the entire fiscal period. If not, then a weighted-average number of shares must be used to adjust the denominator of fully diluted earnings per share. The net earnings available to common shareholders is adjusted on the assumption that the proceeds from the options or warrants had been in- 
Table 2

PANEL B: UK (SSAP 3, as amended by FRS 3)

Basic EPS $=\frac{6,300,000-(600,000)(0.20)}{3,300,000}=\frac{6,180,000}{3,300,000}=1.87$

For the warrants - Fully Diluted:

$$
\frac{\Delta N}{\Delta D}=\frac{(0.05)(500,000)(60)}{500,000}=\frac{1,500,000}{500,000}
$$

since the numerator assumes that the proceeds from the warrants are invested on the first day of the accounting period in $2.5 \%$ Consolidated Stock. The market yield on the $2.5 \%$ Consolidated Stock is calculated as: $(2.5 \% / 50)(100)=5 \%$ where 50 is the market price per common at the beginning of the period. The denominator assumes the maximum number of shares in the conversion.

For the conv. debt using the If-Converted Method:

$$
\frac{\Delta \mathrm{N}}{\Delta \mathrm{D}}=\frac{(1-.40)[(10 \%)(10,000,000)+(200,000) / 10]}{10,000(40)}=\frac{612,000}{400,000}
$$

The Fully Diluted EPS calculation:

$$
\begin{aligned}
& 6,180,000 \div 3,300,000=1.87 \\
& +\quad 612,000 \quad 400,000 \\
& \overline{6,792,000} \div \frac{4,700,000}{3,00} 1.84 \text { Fully Diluted }
\end{aligned}
$$

The conv. debt went into the calculation first since it was the most dilutive (i.e. lowers basic EPS the most). The warrants are assumed not to convert since they would be antidilutive (i.e. increase EPS once the debt was assumed converted). SSAP 3 and FRS 3 do not allow the inclusion of antidilutive securities in the fully diluted calculation.

The 5\% Materiality Test:

$(95 \%)(1.87)=1.75<1.84$ So, Report only Basic.

On the 1996 Profit and Loss Statement show:

Net Income $\begin{array}{r}\text { Basic } \\ \$ 1.87\end{array}$

Of course, the \$ should be reported in English pounds.

vested in $2 \frac{1 / 2}{2}$ percent Consolidated Stock on the first day of the current fiscal period, net of tax. The closing price of the Consolidated Stock on the last day of the previous fiscal period is used as the proxy for the price per share on the first day of the current fiscal period. In Table 2, Panel B, the impact of the warrants has a $\$ 1,500,000$ increment to the numerator, and a
500,000 increment to the denominator in the fully diluted EPS computation.

When a firm has convertible securities, convertible loan stock (debentures) or convertible preferred stock, fully diluted earnings per share should be calculated on the assumption that the new common shares had been issued on the first day of the current fiscal period (i.e. same as the "if-converted" method in the United States). If however, the convertible securities were issued during the current year, the denominator should be adjusted according to a weightedaverage number of shares issued. The net earnings available to common shareholders should be adjusted by adding back the interest saved on the convertible loans, net of tax, or the preferred share dividends on the convertible preferred issue. In Table 2, Panel B, the debt issue has a $\$ 612,000$ increment to the numerator, and a 400,000 share increment to the denominator when computing fully diluted EPS.

However, there are three instances where the disclosure of fully diluted earnings is not required: (1) whenever there is a loss in the current period, resulting in a negative earnings per share measure, (2) if fully diluted earnings per share is greater than basic earnings per share (i.e., antidilutive), or (3) if the dilution is less than five-percent of basic earnings per share. Note that this is the case in Table 2, Panel B since the fivepercent materiality test fails and only basic EPS need be reported.

As in the case of Opinion No. 15 in the United States, SSAP 3 as amended attempted to provide the users of financial statements in the United Kingdom with useful information pertaining to the impact of potentially dilutive securities upon the earnings per share measure. Ideally, this helped investors to make better buy or sell decisions or helped creditors to make better 
credit decisions. Unlike U.S. GAAP, there was no intermediate measure such as primary EPS that was required, the treasury stock method allowed more dilution, and the materiality test was slightly different.

\section{International Harmonization}

The move to a new standard in the United States by the FASB should improve the comparability of EPS measures on a global scale. Exposure Drafts by the IASC (IASC, 1996) and the FASB (FASB, 1996) have been officially released, and final approval by the FASB is expected in mid-1997. Key features of the new United States standard will be:

- Replace "primary earnings per share" with "basic earnings per share."

- Calculate basic earnings per share by dividing income available to common shareholders by a weighted-average number of common shares outstanding during the period.

- Replace the "fully diluted earnings per share" with "diluted earnings per share."

- Calculate diluted earnings per share by using the if-converted and treasury stock methods prescribed by APB No. 15. The modified treasury stock method is eliminated, and the average price of the common is used to calculate the incremental number of shares in the treasury stock method for diluted EPS.

- Include all dilutive securities in the calculations of diluted EPS regardless of the period of time in which they must be exercised or issued.

- Options or warrants that expire during the current period should be included in the period's diluted EPS.

- The "control" number for determining when adding incremental shares to the denominator of the diluted EPS calculation is antidilutive should be income from continuing operations.

- Require presentation of basic and diluted EPS on the face of the income statement for all companies with complex capital structures, even if they are the same amount.

- Require the presentation of EPS amounts for income from continuing operations and net income on the face of the income statement as well as disclosure of per share amounts for discontinued operations, extraordinary items, and the cumulative effect of an accounting change either on the face or footnotes.

- Require disclosure of a reconciliation of the numerator and denominator used in the basic EPS computation to the numerator and denominator used in the diluted EPS computation.

- Retain the scope of APB Opinion No. 15 and add a provision that any non-public company that discloses EPS must do so in accordance with the new standard.

The FASB's and IASC's exposure drafts are almost identical with regard to the computation of EPS measures (Blasch et. al, 1996, pp. 45). Through this new standard, basic earnings per share will be comparable across countries and will be reported on the face of all income statements. This was not the case under APB Opinion No. 15 if the materiality test passed, whereby only primary and fully diluted were reported while basic EPS was not.

Practitioners and academicians should applaud this proposal since the ad-hoc, twothirds test used in determining common stock equivalency status will no longer be required due to the elimination of the primary EPS (see Jerris, 1992b). Hence, one potentially large calculation has been wiped out. Further, diluted EPS will be more comparable since the United States and the IASC will use the same treasury stock method in assessing the dilutive impact of options, and the if-converted method in assessing the potential dilution of convertible debt. To see an illustration of the computations required under the FASB's proposal, see Table 2, Panel C. [D

\section{References}

1. Accounting Principles Board, Opinion No. 15, "Earnings Per Share" (May 1969).

2. Blasch, D. M., J. Kelliher, and W. J. Read, "The FASB and the IASC Redeliberate EPS," Journal of Accountancy (February 1996), pp. 43-47. 
Table 2

PANEL C: FASB's (and IASC's) NEW PROPOSED EPS STANDARD

Basic EPS $=\underline{10,300,000-(600,000)(0.20)}=\underline{10,180,000}=3.08$

$$
3,300,000 \longrightarrow \frac{10,180,000}{3,300,000}
$$

For the warrants using the Treasury Stock Method - Diluted:

$$
\frac{\Delta \mathrm{N}}{\Delta \mathrm{D}}=\frac{0}{(500,000-500,000(60 / 80))}=\frac{0}{125,000}
$$

For the conv. debt using the If-Converted Method:

$$
\frac{\Delta \mathrm{N}}{\Delta \mathrm{D}}=\frac{(1-.40)[(10 \%)(10,000,000)+(200,000) / 10]}{10,000(40)}=\underline{612,000}
$$

The Diluted EPS calculation:

$$
\begin{aligned}
& 10,180,000 \div 3,300,000=3.08 \\
+\frac{0}{10,180,000} \div \frac{125,000}{3,425,000} & =2.97 \\
+\quad \frac{612,000}{10,792,000} \div \frac{400,000}{3,825,000} & =2.82 \text { Diluted }
\end{aligned}
$$

On the 1996 Income Statement show:

$\begin{array}{lcc} & \text { Basic } & \text { Diluted } \\ \text { Continuing Operations } & \$ 3.08 & \$ 2.82 \\ \text { Extraordinary Items } & \underline{(1.21)} & \underline{(1.05)} \\ \text { Net Income } & \underline{\$ 1.87} & \underline{\$ 1.77}\end{array}$

Extraordinary items EPS numbers are derived by dividing the $\$ 4,000,000$ by the number of shares in Basic and Diluted, respectively.

3. Davies, M. R. Paterson, and A. Wilson, Generally Accepted Accounting Practice in the U.K., (Arthur Young: 1989), pp. 263297.

4. Generally Accepted Accounting Practice in the U.K.,(Macmillan: 1994), pp. 1199-1239.

5. Financial Accounting Standards Board, "Earnings per Share and Disclosure of Information about Capital Structure", Exposure Draft No. 157-B, (January 19, 1996).

6. International Accounting Standards Committee, Proposed International Accounting Standard: Earnings Per Share, (June 30, 1996).

7. Jerris, S., "The Association Between Stock Returns and Dilutive Earnings Per Share Numbers: A Reexamination," Journal of
Applied Business Research (Winter 1990-1), pp. 99-105.

8.

"Option-Based EPS

Measures: An Alternative to Primary and Fully Diluted EPS," Journal of Business Finance and Accounting (April 1992), pp. 345-362.

9. "EPS Reporting Revisited: An Evaluation of Proposed Changes," Journal of Applied Business Research (Spring 1992), pp. 25-30.

10. Kross, W. G. Chapman and K. H. Strand, "Fully Diluted Earnings Per Share and Security Returns: Some Additional Evidence," Journal of Accounting, Auditing, and Finance (Fall 1980), pp. 47-56.

11. "News," Journal of Accountancy (June 1994), pp. 19-20. 
